\title{
Application of Learning Model Strategies to improve Islamic Learning Outcomes
}

\author{
Akrim \\ Lecturer at Muhammadiyah University, North Sumatera, Indonesia \\ akrim@umsu.ac.id
}

\begin{abstract}
This study aims to analyze the learning process of Islamic religious education in junior high schools. This study uses qualitative research, with the phenomenological approach of AlUlum MedanJakarta Integrated Islamic Middle School. Data collection techniques used in this study were observation, interviews, focus group discussions and documentation and then analyzed descriptively with an interactive analysis model. The results obtained are modeling learning strategies that have a good impact on improving student learning outcomes, by making some characters become models who practice certain materials in the learning process, so learning to dance from opening, core activities to closing. The conclusion of this study is the modeling learning strategy designed by the Al-Ulum Integrated Islamic Middle School to be superior and integrated characteristics of a junior high school, modeling learning strategies pay attention to the interests of students, the learning outcomes of Islamic religious education taught with modeling learning strategies are higher than those taught with conventional learning strategies.
\end{abstract}

Keywords

learning strategies; PAI

modeling; learning

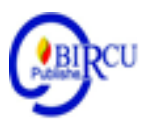

\section{Introduction}

Islamic religious education learning that has been going on seems to be less related or less concerned with the problem of how to change religious knowledge that is cognitive to be "meaning" and "value" (Muhaimin, 2004) that needs to be internalized in students (Daulay, 2012), henceforth to be a source of motivation for students to move, act and behave in a concrete religious way in real-life everyday (Tobroni, 2008)

When we observe the empirical phonomene that is in front of and around us, it appears that at this time there are many cases of delinquency among students (Syifaunnufush \& Diana, 2017). Issues of student fights, violence, thuggery, alcohol consumption, traffic ethics, crime that is becoming more and more complicated, have colored the pages of newspapers, magazines and other mass media (Maulida, 2016). The emergence of these cases is not merely the failure of Islamic Religious Education in schools that emphasizes cognitive aspects, but how all of that can encourage and move Islamic Religious Education Teachers to re-examine and find solutions through the development of Islamic religious education learning (Priatna, 2015).

In developing curriculum and learning in Islamic religious education things must be considered as follows: (1) what will be taught, (2) how to teach, and (3) how to know that what is taught has been mastered or owned by students (Sulasmi, 2019). What is meant in the second question concerns what teaching strategies and teaching aids will be used in the learning of Islamic religious education.

Learning model is a plan or a pattern that is used as a guide in planning learning in class or learning in tutorials and to determine learning tools including books, films, computers, curriculum and others. (Suryono, 2020) Meanwhile according to Soekamto, et al. 
(Giri Wiarto 2015,77) learning models have meaning, namely: Learning model is a conceptual framework that describes a systematic procedure in organizing learning experiences to achieve certain learning goals, and serves as a guide for learning designers and instructors in planning teaching and learning activities.

With regard to learning strategies, the teacher has a strategic role in designing a strategy, technique, or approach that is deemed appropriate for achieving learning objectives (Sulasmi, 2020a). As a designer in learning, the teacher is very instrumental in determining the success or failure of the achievement of learning objectives. So that learning objectives can be achieved, teachers are required to have skills and can organize materials in such a way that the learning materials become interesting and challenging. But now there is a tendency that teachers often use learning techniques that do not foster the potential of students' thinking, attitudes, and skills. Somantri (2001) suggests that the use of such learning techniques is caused by several factors, namely, the habit of learning techniques that have been institutionalized for a long time and those learning techniques are the easiest to do.

In fact, although the learning objectives have been clearly and clearly established, the implementation of learning often fails. This indicator is seen in the low quality of education in Indonesia. And the results of several studies indicate that graduates of elementary schools (SD), junior high schools (SMP), and senior high schools (SMA) only master about 30 percent of educational material (Azari, 2000).

The process of organizing education is still dominated by the view that knowledge as a set of facts that must be memorized will clearly produce unsatisfactory learning outcomes, due to various things including the selection of inappropriate learning strategies (Sulasmi, 2020b). To obtain learning outcomes that are in accordance with the learning objectives requires the ability to choose the right learning strategy, because the learning strategy is the most important thing that must be considered in a teaching and learning process. The learning strategy chosen should be adapted to methods, media and other learning resources that are considered relevant in conveying information, and guide students to get involved optimally, so students can gain learning experiences in order to grow and develop their abilities, such as: mental, intellectual, emotional, and social as well as skills or cognitive, affective and psychomotor. Thus, the selection of appropriate learning strategies can arouse and encourage the emergence of student activities to improve students' abilities and understanding of certain subject matter.

Based on the description above, it can be seen that to obtain learning outcomes as expected we need a learning strategy that is able to further empower students in a teaching and learning process. Therefore, it is necessary to conduct an assessment and renewal (innovation) in learning strategies using modeling. By learning through modeling, students can observe objects or objects directly that become models that are emulated, admired, and trusted by students so that they represent the actual objects or objects that are expected. Objects or objects that are used as models that reflect or represent an object or object that is actually, and that is what is observed, and understood by students (WS, 1989).

This phenomenon was found in this study. Al-Ulum Integrated Islamic Middle School, has advantages and uniqueness in managing the learning process of Islamic religious education, which designs learning every day to achieve the expected learning outcomes, Islamic religious education learning that is applied at Al-Ulum Integrated Islamic Middle School Medan by applying modeling learning strategies . By paying attention to the right learning strategies and also the right approach for all students, it can improve the quality of Islamic education better in Islamic educational institutions (SF Shah, SR Ghazi, 2015). 
Based on this, the scope and formulation of the problem in this study are "How can the modeling learning strategy improve the learning outcomes of Islamic Religious Education in Al-Ulum Integrated Islamic Middle School Medan?" And the purpose of this research is to analyze descriptively modeling learning strategies in improving learning outcomes of Islamic Religious Education in Al-Ulum Islamic Middle School Medan.

\section{Research Method}

The location of this study is Al-Ulum Integrated Islamic Middle School, which is located on Jl. Lever No. 35 Medan. The time specified in conducting this research is the 2019/2020 school year.

The reason for choosing a research location is; 1) Al-Ulum Integrated Islamic Middle School has implemented an integrated Islamic education system since 2004, 2) has competent teachers to develop Islamic Religious Education learning, 3) has strategies and learning methods that are suitable for all students, 4) many achievements include: Champion I Medan City Level Achievement School in 2013, Award of Islamic Education Award from the Regional Office of the Ministry of Religion in 2016, 5) has relatively adequate and representative facilities 6) Al-Ulum Integrated Islamic Middle School is an Islamic educational institution that is in great demand by the community, as proven with the number of pivot before the opening of new student registration every year, and 7) Al-Ulum Integrated Islamic Middle School is a pilot school in implementing an integrated learning system, which is visited by many other schools from various regions in Indonesia for comparative studies.

This type of research is a qualitative research with a phenomenological type approach, which is characteristic: describing data, analyzing, and interpreting phenomena captured in RA field observations. An-Nahl, Jakarta. Bogdan and Biklen suggest, "Researchers in the phenomenological model try to understand the meaning of events and interactions with people, usually in certain situations" (Bogdan, 1992).

This qualitative research is a field research, which is a research that collects data and train information circulating directly to the location or object to be studied, namely Al-Ulum Integrated Islamic Middle School. The basic data in this study is a daily learning flow conducted by Al-Ulum Integrated Islamic Middle School teachers based on integrated education.

The main informants of this study are the Principal as the policy controller, the integrated education coordinator as the person in charge, and the teaching staff as the implementer of integrated education. How to determine informants using purposive techniques and key respondents in accordance with research objectives. The main informant is expected to be able to provide data on Islamic learning education learning with modeling learning strategies.

Data collection techniques used in this study, namely: 1) observation, researchers observe the process of day flow that is designed and implemented by teachers in the learning process based on modeling learning strategies, 2) interviews, to principals, as well as educators and education (teachers and staff ) Al-Ulum Integrated Islamic Middle School as the main respondent for researchers to get information about modeling learning strategies, 3) Focus Group Discussion (FGD), the researchers joined the staff and teachers of Al-Ulum Integrated Islamic Middle School in focus group discussions, which were conducted every day after teaching and learning activities at school.

Data analysis techniques in this study used the Miles and Huberman Interactive Analysis models. This interactive analysis model consists of four main things, namely: (1) 
data collection; (2) data condensation; (3) display data, and; (4) conclusion: draw / verify. (Miles, MB \& Huberman, AM) Qualitative Data Analysis: Logbook expanded 2nd edition). The four activities are activities that are intertwined at the time before, during, and after collecting data in parallel form to build a general insight called analysis. The data obtained are generally in the form of words, the results of research analysis are presented in descriptive form.

In qualitative research, testing the validity of data can be achieved by triangulating data and informants. This means that the researcher must clarify the findings of a third person, or the same person at different times. If the information is received, either by another person or the same person, but at different times it still produces the same information, the data is declared "saturated". That's when the validity and reliability of research data has been achieved (Idrus, 2009).

\section{Discussion}

The learning steps using modeling in the form of: (1) seeing the behavior of the model that should be imitated by students; (2) establish functional values of behavior and models; (3) developing learning sequences; (4) applying learning to guide students' cognitive and motor reproduction processes. The implementation of its learning focuses on the influence of modeling with the learning process taking place in stages and simple to complex skills so that it is easy to identify the talents, interests, and abilities of students. The basis for learning is the relationship between students and models and reinforcement and punishment and observation. Through reinforcement and punishment received by students both directly and indirectly can shape student behavior that is expected and eliminate unexpected behavior. To provide reinforcement and punishment, teachers must pay attention that giving reinforcement and punishment should not be excessive because students can lose self-control. In addition, reinforcement and punishment given to students through modeling is very helpful for teachers in improving student learning outcomes. Reinforcement gives functional value to the behavior of students about the positive consequences of the task that has been completed, while the penalty provides a functional value of behavior to the negative consequences received by students if they do not complete the task.

The virtue of learning by using modeling is that in designing teacher learning it can determine which behavioral choices will be made from the model and adjust the type of model to be used according to student characteristics and subjects as well as the results of the behavior that students will master after participating in a unit of learning activities. In addition, students are more democratic in choosing which behaviors will be copied from the model. In learning using the teacher's role modeling as a guide and motivator, the teacher then provides assistance and explains the learning process taken, inviting students to think critically, analytically, reflective, openly and able to develop the abilities of students through learning experiences, so that the element of excitement from self-expression can created and planned by the teacher.

By learning through modeling students become more active and creative, considering learning will be more meaningful if cognitive, affective, and psychomotor functions can work together. In modeling students learn by watching and observing the behavior of the model. Learning support materials are very numerous and are available around students. Therefore, teachers can plan learning activities inside and outside the classroom.

Student learning progress by using modeling is assessed from the learning process and learning achievement test, students who get high learning outcomes will be a model for students who get low learning outcomes. Thus, students will obtain learning outcomes by 
observing each action carried out by the model. Eventually these attitudes and behaviors become a part of him, High and low learning outcomes have an impact on self-confidence, hopes and ideals.

Islamic religious education has functions including: (a) developing knowledge about spatial patterns and related processes, (b) developing basic skills in obtaining and information, communicating and applying knowledge of Islamic religious education, and (c) growing attitudes, awareness and environmental stewardship and tolerance resources for the socio-cultural diversity of the community.

Islamic religious education has a very broad scope, thus learning activities must provide opportunities for students to respond to the subject matter critically, analytically so that the values contained in Islamic religious education subjects are truly understood and believed by students, so students can implement in everyday life. For this reason, teachers are expected to have knowledge and understanding of learning strategies, because knowledge and understanding of learning strategies is very important as an effort to provide optimal student learning experience and achievement. In this case, teachers are required to be able to improve the quality of learning and must pay attention to the nature, objectives of the subjects to be taught, and consider the characteristics of students. That is, a teacher must be able to determine which strategy is most appropriate so that it matches the objectives and the material to be conveyed.

Islamic religious education learning with conventional learning strategies, has the following learning steps; (1) apperception in the introduction; (2) main activities, namely the description of the material in which the teacher's activities are usually carried out by the lecture method; (3) closing by summarizing, concluding, evaluating, and following up on the subjects that have been given. Learning is only presented in class, carried out to groups as a whole and students learn through understanding, making it difficult to identify students' talents, interests, and abilities. The basis for learning through perception is the key to understanding subjects. Learning without using a model, the role of students is only to listen carefully and record important material presented by the teacher. In learning activities, the teacher is difficult to determine the reinforcement and punishment that will be given to students.

The learning steps use modeling in the form of: (1) seeing and observing models or objects that should be emulated or used as examples by students; (2) determine the functional value of the model or object used as an example; (3) developing learning sequences; (4) applying learning to guide students' cognitive and motor reproduction processes. The implementation of its learning focuses on the influence of modeling with the learning process progressing gradually from simple to complex skills so that it is easy to identify the talents, interests, and abilities of students. The basis for learning is the relationship between students and models, and the reinforcement and punishment of observation. Through reinforcement and punishment received by students both directly and indirectly can shape student behavior that is expected and eliminate unexpected behavior. To provide reinforcement and punishment, teachers must pay attention that giving reinforcement and punishment should not be excessive because students can lose self-control. In addition, reinforcement and punishment given to students through modeling really helps the teacher in improving student learning outcomes. Reinforcement gives functional value to the behavior of students about the positive consequences of the task that has been completed, while the punishment provides functional value of the behavior to the negative consequences received by students if they do not complete the task.

Based on the results of research conducted it can be seen that the learning outcomes of Islamic religious education students who are taught with modeling learning strategies obtain 
an average score of 18.87 and the average score of conventional learning is 18.25 . From the difference in average scores and the results of hypothesis testing it is evident that the learning outcomes of Islamic religious education students who are taught with modeling learning strategies are higher than students who are taught with conventional learning strategies.

If we pay attention to the sequence of learning steps of the two learning models above, it can be seen that the learning outcomes of Islamic religious education students who are taught with modeling learning strategies are higher than conventional learning strategies. The virtue of learning by using modeling is in designing teacher learning can determine the selection of characteristics or behavior which will be done from the model or object used as an example and adjust the type of model to be used according to student characteristics and subjects as well as the results of which behavior will controlled by students after participating in a unit of learning activities.

Modeling learning can improve students' mindset to behave and act more democratically in choosing which characteristics / behaviors will be copied from the model. Through this modeling learning the teacher can stimulate and direct students to think critically, analytically, reflectively, and openly which in turn greatly influences their learning outcomes. This finding supports the results of Evi Susilawati's (2005) study which states that modeling learning models can encourage students to behave and act scientifically, and provide learning experiences that enable students to engage physically, emotionally, and mentally in learning activities so that there are differences in PPKn learning outcomes between students who are taught with modeling and conventional learning models. It was further stated that the learning outcomes of PPKn students who were taught with modeling learning models were higher than conventional learning models.

Furthermore, Usmaidar (2007) suggested that modeling learning, students learn by watching and observing the behavior of the model. Learning support materials are very numerous and are found around students. Therefore, teachers can plan learning activities inside and outside the classroom. The teacher acts as a guide and motivator, where the teacher provides help and explains the learning process taken, invites students to think critically, analytically, reflective, openly and is able to develop the abilities of students through learning experiences, so that the element of joy from self-expression can be created and planned by the teacher. By learning through modeling students become more active and creative, considering learning will be more meaningful if cognitive, affective, and psychomotor functions can work together. The results of this study support the study of Sopah (1999) which states that the ARIAS learning model is a learning model that can foster attention, confidence, activeness, and feels pleasing to students, so that the learning outcomes of students who are taught with ARIAS learning models are higher than non learning models -ARIAS.

Based on the description above, the following illustrates the difference between modeling learning strategies and conventional learning strategies:

Table 1. Differences in Modeling Learning Strategies with Conventional

\begin{tabular}{|c|l|l|}
\hline No & \multicolumn{1}{|c|}{$\begin{array}{c}\text { Learning strategies } \\
\text { Modeling }\end{array}$} & \multicolumn{1}{c|}{$\begin{array}{c}\text { Conventional Learning } \\
\text { Strategies }\end{array}$} \\
\hline $\mathbf{1}$ & Learning through models & Learning through understanding \\
\hline $\mathbf{2}$ & $\begin{array}{l}\text { The teacher can plan learning inside } \\
\text { and outside the classroom } \\
\text { environment }\end{array}$ & $\begin{array}{l}\text { The teacher can plan learning only in } \\
\text { the classroom environment }\end{array}$ \\
\hline $\mathbf{3}$ & Elements of excitement and self- & The element of joy and self- \\
\hline
\end{tabular}




\begin{tabular}{|c|l|l|}
\hline & $\begin{array}{l}\text { expression in learning can be created } \\
\text { and planned }\end{array}$ & $\begin{array}{l}\text { expression in learning, if any, } \\
\text { happens by accident }\end{array}$ \\
\hline $\mathbf{4}$ & $\begin{array}{l}\text { A gradual process, from simple to } \\
\text { complex skills }\end{array}$ & $\begin{array}{l}\text { The learning process starts from the } \\
\text { whole }\end{array}$ \\
\hline $\mathbf{5}$ & Learn by using models & Learning without using a model \\
$\mathbf{6}$ & $\begin{array}{l}\text { The basis for learning is the } \\
\text { relationship between students and } \\
\text { models and the provision of } \\
\text { reinforcement and punishment from } \\
\text { observation }\end{array}$ & $\begin{array}{l}\text { The basis of learning is perception as } \\
\text { a key to understanding in learning }\end{array}$ \\
\hline $\mathbf{7}$ & $\begin{array}{l}\text { Easily identify student talents, } \\
\text { interests and abilities }\end{array}$ & $\begin{array}{l}\text { Difficult to identify interest in } \\
\text { students' abilities and abilities }\end{array}$ \\
\hline
\end{tabular}

Student learning progress using modeling is assessed from the learning process and learning achievement tests. Students who get high learning outcomes will be a model for students who get low learning outcomes. Students get learning outcomes by observing every action implemented by the model. Finally, the attitude and behavior becomes part of him, the high and low learning outcomes have an impact on self-confidence, hopes and ideals.

While the learning strategy using the conventional approach is a teacher-oriented learning approach, the teacher's meaning is the only source of information and knowledge of students (teacher center). This learning strategy is teacher-oriented and lectures are usually the first choice of learning methods. Conditions like this will result in students not being empowered to find the knowledge they need, so students get the knowledge and knowledge based on what is conveyed by the teacher alone. In line with this opinion, the findings of Nawawi (2004) suggest that the conventional learning model is a learning model whose learning strategy uses the teacher as the only source of learning, meaning that the teacher is the holder of control and control in determining content, methods, and assessing student learning outcomes.

Furthermore, learning with a conventional approach does not encourage the growth of a sense of curiosity and a sense of responsibility of students in planning and organizing ways of learning. As a result, students 'knowledge and skills are only in short-term memory, and will tend to be incapable of increasing students' retention of subject matter. In learning the communication that takes place in a one-way learning process, it tends to cause students to understand the concepts and terms.

Dick and Carey (2006) suggested that conventional learning strategies tend to use memorization and lead more to the memorization aspect, which emphasizes the element of memory, so students gain knowledge and skills by connecting words with subjects repeatedly, which in the end if students have not memorized it perfectly, then the material cannot be continued or added. In this strategy, a teacher who has a greater role means that students are not directly involved in searching for and finding important learning materials, so that the knowledge and skills acquired are not able to increase student retention and memory or are only in short-term memory. Finally, student success in learning depends very much on the teacher's delivery, ability, and teacher experience. Learning like this will have the potential to provide the acquisition of learning results that are less than the maximum.

From the description above, it can be understood that the learning outcomes of Islamic religious education students who are taught with modeling learning strategies are higher than conventional learning strategies. Strengthening these findings is described learning outcomes data as follows: 


\section{a. Learning outcomes using Strategy Modeling}

Table-2. Frequency Distribution of Learning Outcomes of Islamic Education for the Treatment of Modeling Learning Strategies

\begin{tabular}{|c|c|c|c|}
\hline Number & Interval Class & $\begin{array}{c}\text { Absolute } \\
\text { Frequency }\end{array}$ & Relative Frequency \\
\hline $\mathbf{1}$ & $\mathbf{9}-\mathbf{1 2}$ & $\mathbf{3}$ & $\mathbf{7 , 5 0 \%}$ \\
\hline $\mathbf{2}$ & $\mathbf{1 3}-\mathbf{1 6}$ & $\mathbf{1 4}$ & $\mathbf{3 5 , 0 0 \%}$ \\
\hline $\mathbf{3}$ & $\mathbf{1 7}-\mathbf{2 0}$ & $\mathbf{8}$ & $\mathbf{2 0 , 0 0 \%}$ \\
\hline $\mathbf{4}$ & $\mathbf{2 1}-\mathbf{2 4}$ & $\mathbf{8}$ & $\mathbf{2 0 , 0 0 \%}$ \\
\hline $\mathbf{5}$ & $\mathbf{2 5}-\mathbf{2 8}$ & $\mathbf{7}$ & $\mathbf{1 7 , 5 0 \%}$ \\
\hline \multicolumn{2}{|c|}{ Total } & $\mathbf{4 0}$ & $\mathbf{1 0 0 \%}$ \\
\hline
\end{tabular}

Data from table- 2 above, it can be seen that there are about $42.50 \%$ of the scores of Islamic religious education learning outcomes for the treatment of learning strategies Modeling is below average, $20.00 \%$ equal to the average, and $37,50 \%$ above average.

\section{b. Learning outcomes using Conventional Strategies}

Table . Frequency Distribution of Learning Outcomes of Islamic Education for the Treatment of Conventional Learning Strategies

\begin{tabular}{|c|c|c|c|}
\hline Number & Interval Class & $\begin{array}{c}\text { Absolute } \\
\text { Frequency }\end{array}$ & $\begin{array}{c}\text { Relative } \\
\text { Frequency }\end{array}$ \\
\hline $\mathbf{1}$ & $\mathbf{1 2}-\mathbf{1 4}$ & $\mathbf{4}$ & $\mathbf{1 0 . 0 0 \%}$ \\
\hline $\mathbf{2}$ & $\mathbf{1 5}-\mathbf{1 7}$ & $\mathbf{6}$ & $\mathbf{1 5 . 0 0 \%}$ \\
\hline $\mathbf{3}$ & $\mathbf{1 8}-\mathbf{2 0}$ & $\mathbf{1 6}$ & $\mathbf{4 0 , 0 0 \%}$ \\
\hline $\mathbf{2 1}$ & $\mathbf{2 1}-\mathbf{2 2}$ & $\mathbf{1 2}$ & $\mathbf{3 0 . 0 0 \%}$ \\
\hline $\mathbf{5}$ & $\mathbf{2 3 - 2 4}$ & $\mathbf{2}$ & $\mathbf{5 . 0 0 \%}$ \\
\hline \multicolumn{2}{|c|}{ Total } & $\mathbf{4 0}$ & $\mathbf{1 0 0 \%}$ \\
\hline
\end{tabular}

Data from Table-2 above, it can be seen that there are about $25.00 \%$ of the scores of Islamic religious education learning outcomes for the treatment of conventional learning strategies are below average, $40.00 \%$ equals the average, and $35.00 \%$ above average.

\section{Conclusion}

Some conclusions from the results of this study are; 1) modeling learning strategies designed by the Al-Ulum Integrated Islamic Middle School to become superior and integrated SMP characteristics; 2) modeling learning strategies pay attention to the interests of students 3) Islamic education learning outcomes taught with modeling learning strategies are higher than those taught with conventional learning strategies, 4) Islamic Middle School Al-Ulum Medan can be used as an example by other similar educational institutions to further improve the quality of learning of Islamic religious education in junior high schools formally. 


\section{References}

Bogdan, R. dan B. (1992). Penelitian Kualitatif untuk Pendidikan: Pengantar Teori dan Metode. Boston: Bacon INc.

Daulay, H. P. dan N. P. (2012). Pendidikan Islam dalam Mencerdaskan Bangsa. Jakarta: Rineka Cipta.

Idrus, M. (2009). Metode Penelitian Ilmu Sosial. Jakarta: Erlangga.

Maulida, P. (2016). Hasil Survei: 45 Persen Remaja Indonesia Usia 13-19 Tahun Sudah Merokok.

Muhaimin. (2004). Paradigma pendidikan Islam: Upaya mengefektifkan Pendidikan Agama Islam di sekolah. Bandung: Remaja Rosdakarya.

Priatna, T. (2015). Model Pembelajaran Pendidikan Agama Islam di Sekolah Berwawasan Kebangsaan (Studi Kasus di Sekolah Menengah Atas Terpadu Krida Nusantara Kota Bandung. UIN Sunan Gunung Djati Bandung.

SF Shah, SR Ghazi, S. S. (2015). Kualitas dan Fitur Pendidikan di Dunia Muslim. Horiz. Res.

Sulasmi, E. (2019). Analisis faktor-faktor yang mempengaruhi prestasi belajar siswa ditinjau dari aspek manajemen belajar siswa (studi pada siswa smp gajah mada medan). (1).

Sulasmi, E. (2020a). Evaluation of Coaching Students Based on Dormitory Curriculum in Madrasah Aliyah Negeri Insan Cendikia Bengkulu Tengah. 640-646.

Sulasmi, E. (2020b). The Development Strategy of Human Resources Management In Children's Social Welfare Institution ( LKSA) ( Case Study in LKSA AL-Mubaraak Orphanage Bengkulu ). 562-569.

Syifaunnufush, A. D., \& Diana, R. R. (2017). Kecenderungan Kenakalan Remaja Ditinjau Dari Kekuatan Karakter Dan Persepsi Komunikasi Empatik Orangtua. Jurnal Psikologi Integratif, 5(1).

Tobroni, A. S. (2008). Pendidikan Islam: Paradigma Teologis, Filosofis dan Spiritualis. UMM Press.

WS, W. (1989). Psikologi Pendidikan. Jakarta: Grasindo.

Bogdan, R. dan B. (1992). Penelitian Kualitatif untuk Pendidikan: Pengantar Teori dan Metode. Boston: Bacon INc.

Daulay, H. P. dan N. P. (2012). Pendidikan Islam dalam Mencerdaskan Bangsa. Jakarta: Rineka Cipta.

Idrus, M. (2009). Metode Penelitian Ilmu Sosial. Jakarta: Erlangga.

Maulida, P. (2016). Hasil Survei: 45 Persen Remaja Indonesia Usia 13-19 Tahun Sudah Merokok.

Muhaimin. (2004). Paradigma pendidikan Islam: Upaya mengefektifkan Pendidikan Agama Islam di sekolah. Bandung: Remaja Rosdakarya.

Priatna, T. (2015). Model Pembelajaran Pendidikan Agama Islam di Sekolah Berwawasan Kebangsaan (Studi Kasus di Sekolah Menengah Atas Terpadu Krida Nusantara Kota Bandung. UIN Sunan Gunung Djati Bandung.

SF Shah, SR Ghazi, S. S. (2015). Kualitas dan Fitur Pendidikan di Dunia Muslim. Horiz. Res.

Sulasmi, E. (2019). Analisis faktor-faktor yang mempengaruhi prestasi belajar siswa ditinjau dari aspek manajemen belajar siswa (studi pada siswa smp gajah mada medan). (1).

Sulasmi, E. (2020a). Evaluation of Coaching Students Based on Dormitory Curriculum in Madrasah Aliyah Negeri Insan Cendikia Bengkulu Tengah. 640-646.

Sulasmi, E. (2020b). The Development Strategy of Human Resources Management In Children's Social Welfare Institution ( LKSA) ( Case Study in LKSA AL-Mubaraak 
Orphanage Bengkulu ). 562-569.

Suryono. (2020). Pride Learning Model in Order to Improve the Physical Fitness of Indonesian Naval Academy Cadets. Budapest International Research in Linguistics and Education Sciences (BirLE), P. 235-243.

Syifaunnufush, A. D., \& Diana, R. R. (2017). Kecenderungan Kenakalan Remaja Ditinjau Dari Kekuatan Karakter Dan Persepsi Komunikasi Empatik Orangtua. Jurnal Psikologi Integratif, 5(1).

Tobroni, A. S. (2008). Pendidikan Islam: Paradigma Teologis, Filosofis dan Spiritualis. UMM Press.

WS, W. (1989). Psikologi Pendidikan. Jakarta: Grasindo. 